\title{
HUBUNGAN KARIES GIGI DENGAN KUALITAS HIDUP PADA ANAK SEKOLAH USIA 5-7 TAHUN
}

\author{
Bunga Nurwati', Darmawan Setijanto ${ }^{2}$, Hendrik Setia Budi ${ }^{3}$ \\ ${ }^{1}$ Poltekkes Kemenkes Banjarmasin, ${ }^{2}$ Departemen IImu Kesehatan Gigi Masyarakat Fakultas \\ Kedokteran Gigi Universitas Airlangga, ${ }^{3}$ Departemen Biologi Oral Fakultas Kedokteran Gigi \\ Universitas Airlangga, Surabaya \\ Email : aisyahhumairo79@gmail.com
}

\begin{abstract}
Abstrak: Karies gigi yang diderita pada anak usia sekolah dapat menyebabkan gangguan kualitas hidup dan terganggunya kegiatan keseharian yang dikarenakan ketidakmampuan proses pengunyahan. Kejadian karies gigi sulung pada anak mencapai $80 \%$ dengan rerata def-t 5,0 yang selanjutnya berakibat pada banyaknya penderita gigi berlubang untuk anak usia dibawah 12 tahun (mencapai 89\%). Sementara WHO mencanangkan target pencapaian pelayanan kesehatan gigi di tahun 2010 sebesar $90 \%$ bebas karies untuk anak usia 5 tahun. Penelitian ini bertujuan untuk menganalisis hubungan antara indeks karies gigi pada anak usia 5-7 tahun dengan kualitas hidup anak tersebut. Metode simple random Lemeshow digunakan sebagai teknik pengambilan sampel. Penelitian dilakukan dengan menggunakan metode observasional analitik berbasis teknik korelasi yang dilakukan pada 138 sampel anak sekolah. Hasil uji korelasi menggunakan nilai $\alpha=0.05$ menunjukkan adanya korelasi yang berlawanan antara indeks karies gigi dengan kualitas hidup anak sekolah. Dimana indeks yang menjadi bahan uji korelasi memberikan hubungan yang signifikan $(p=0,039)$ yang artinya $p<0.05$ terhadap variabel yang diuji. Kesimpulan semakin rendah indeks karies gigi, semakin tinggi kualitas hidup anak sekolah.
\end{abstract}

Kata kunci: karies gigi, indeks def-t, kualitas hidup, ECOHIS.

Abstract: Dental caries suffered in school-age children can cause disruption in quality of life and disruption of daily activities due to the inability of the mastication process. The incidence of primary dental caries in children reaches $80 \%$ with a mean def-t 5.0 which in turn results in many cavities for children under 12 years old (reaching 89\%). While WHO announced the target of achieving dental health services in 2010 amounting to $90 \%$ of caries-free for children aged 5 years. This study aims to analyze the relationship between the index of dental caries in children aged 5-7 years with the quality of life of the child. Where the simple random Lemeshow method is used as a sampling technique. The study was conducted using an observational analytic method based on correlation techniques conducted on 138 samples of school children. Correlation test results using the value $\alpha=0.05$ showed an opposite correlation between the index of dental caries and the quality of life of school children. Where the index which is the material for the correlation test gives a significant relationship $(p<0.05)$ to the variables tested. Conclusion The lower the dental caries index, the higher the quality of life of school children.

Keywords: dental caries, def-t index, quality of life, Early Childhood Oral Health Impact Scale.

Copyright (C) 2019 Jurnal Skala Kesehatan. Politeknik Kesehatan Banjarmasin All rights reserved

Corresponding Author:

Bunga Nurwati

Poltekkes Kemenkes Banjarmasin Jurusan

Keperawatan Gigi Jln H. Mistar Cokrokusumo

Banjarbaru

Email : aisyahhumairo79@gmail.com 


\section{PENDAHULUAN}

Rerata karies penduduk Indonesia sebesar 4,6 atau sekitar 5 buah gigi perorang (Riskesdas, 2013). Penelitian yang dilakukan oleh beberapa peneliti menunjukkan adanya angka karies gigi pada anak usia 12 tahun sebesar 3,8 pada kecamatan Tomohon Selatan, dan 3,35 pada anak di propinsi Kalimantan Barat. Hal ini menunjukkan angka karies gigi pada anak usia 12 tahun masih tinggi dengan rerata 4 gigi yang mengalami kerusakan. ${ }^{22,34}$

Karies gigi yang melibatkan pulpa pada gigi sulung sebesar $62 \%$ untuk anak usia 6 tahun dan karies gigi permanen sebesar $65,8 \%$ untuk anak usia 8 tahun. ${ }^{26} \mathrm{Hal}$ ini dapat disimpulkan bahwa anak dalam periode gigi bercampur memperlihatkan karies gigi yang parah. Keadaan mulut yang buruk, misalnya dengan banyaknya gigi yang hilang sebagai akibat gigi rusak atau trauma yang tidak dirawat, akan mengganggu fungsi dan aktivitas rongga mulut sehingga akan mempengaruhi status gizi serta akan mempunyai dampak pada kualitas hidup. Pada masa anak-anak, kondisi tersebut akan mempunyai dampak pada tumbuh kembang dan kesejahteraan anak. ${ }^{29}$ Anak-anak yang mempunyai kesehatan mulut buruk, 12 kali lebih banyak menderita gangguan aktivitas, termasuk tidak masuk sekolah dibandingkan dengan mereka yang mempunyai kesehatan mulut yang baik..$^{19,32}$

Karies yang sudah lanjut dapat mempengaruhi kesehatan dan kualitas hidup seseorang yang menyebabkan rasa sakit, sulit tidur dan makan, menurunnya indeks massa tubuh, tidak masuk sekolah bahkan rawat inap serta biaya yang dikeluarkan untuk pengobatan karies yang parah lebih tinggi daripada kasus lesi yang awal. Keadaan mulut yang buruk, misalnya banyaknya gigi hilang sebagai akibat gigi rusak atau trauma yang tidak dirawat, akan mengganggu fungsi dan aktivitas rongga mulut sehingga hal ini juga mempengaruhi tumbuh kembang anak yang berdampak pada kualitas hidup. Tujuan penelitain untuk menganalisa dampak karies gigi yang diderita anak sekolah usia 5-7 dengan kualitas hidup. ${ }^{6}$

\section{BAHAN DAN METODE}

Metode penelitian yang digunakan adalah observasional analitik dengan rancangan penelitian cross sectional. Populasi pada penelitian ini adalah anak usia 5-7 tahun dan orang tua. Jumlah sampel dalam penelitian ini adalah 138 orang anak usia 5-7 tahun yang memiliki karies gigi. Sampel diambil dengan cara purposive sampling. Instrument penelitian karies gigi diukur dengan menggunakan indeks def-t. Kualitas hidup menggunakan kuesioner Early Childhood Oral Health Impact Scale (ECOHIS). ${ }^{25}$

\section{HASIL DAN PEMBAHASAN}

Tabel 1. Karakteristik Demografi dan Karies Gigi anak usia 5-7 tahun

\begin{tabular}{lcc}
\hline \multicolumn{1}{c}{$\begin{array}{c}\text { Karakteristik Demografi dan Karies } \\
\text { Gigi }\end{array}$} & $\mathbf{n}$ & Frekuensi \\
\cline { 2 - 3 } Karakteristik anak & & \\
Usia & 46 & 33.3 \\
5 tahun & 46 & 33.3 \\
6 tahun & 46 & 33.3 \\
7 tahun & & \\
Jenis Kelamin & 63 & 47.1 \\
Laki-laki & 75 & 52.9 \\
Perempuan & & \\
Tingkatan Sekolah & 46 & 33.33 \\
TK & 92 & 66.7 \\
SD & Laki-laki (\%) & Perempuan (\%) \\
Karies gigi & & $11(7.97 \%)$ \\
def & $7(5.07 \%)$ & $15(10.86 \%)$ \\
Rendah & $13(9.42 \%)$ & $47(34.05 \%)$ \\
Sedang & $45(32.60 \%)$ & \\
Tinggi & 9.05 & \\
Rerata def & & \\
&
\end{tabular}


Tabel 1 menunjukkan karakteristik anak usia 5-7 tahun berjumlah masing-masing sebanyak 46 orang anak. Jenis kelamin perempuan sebanyak 75 orang anak $(52.9 \%)$ dan jenis kelamin laki-laki sebanyak 63 orang anak (47.1\%). Jumlah anak yang duduk dibangku SD sebanyak 92 orang anak (66.7\%) dan dibangku Taman Kanak-kanak sebanyak 46 orang anak (33.33\%).

Karakteristik karies gigi pada anak usia 5-7 lebih banyak diderita anak perempuan (34.0\%) dibandingkan dengan anak laki-laki (32.60\%). Rerata karies gigi sulung yang diderita anak sebesar 9.05 .

Tabel 2. Distribusi frekuensi antara karies gigi dengan gangguan rasa sakit, fungsional, dan interaksi sosial pada anak usia 5-7 tahun.

\begin{tabular}{|c|c|c|c|c|}
\hline \multirow{3}{*}{ Pernyataan } & \multicolumn{4}{|c|}{ Pilihan Jawaban } \\
\hline & TP & HTP & $\mathbf{S}$ & SS \\
\hline & n (\%) & n (\%) & n (\%) & n (\%) \\
\hline $\begin{array}{l}\text { Gangguan pada anak (rasa } \\
\text { sakit/nyeri) }\end{array}$ & $30(21.7)$ & $26(18.8)$ & $80(58.0)$ & $2(1.4)$ \\
\hline \multicolumn{5}{|l|}{ Gangguan fungsional } \\
\hline $\begin{array}{l}\text { - Kesulitan minum minuman } \\
\text { panas atau dingin }\end{array}$ & $58(42.0)$ & $19(13.8)$ & $61(44.2)$ & $0(0)$ \\
\hline $\begin{array}{l}\text { - Kesulitan makan beberapa } \\
\text { makanan }\end{array}$ & $48(34.8)$ & $37(26.8)$ & $51(37.0)$ & $2(1.4)$ \\
\hline - Kesulitan dalam berbicara & $75(54.3)$ & $27(19.6)$ & $36(26.1)$ & $0(0)$ \\
\hline - Tidak masuk sekolah & $76(55.1)$ & $24(17.4)$ & $38(27.5)$ & $0(0)$ \\
\hline \multicolumn{5}{|l|}{ Gangguan psikologis } \\
\hline -Kesulitan tidur & $58(42.0)$ & $28(20.3)$ & $52(37.7)$ & $0(0)$ \\
\hline -Mudah marah dan frustasi & $89(64.5)$ & $30(21.7)$ & $19(13.8)$ & $0(0)$ \\
\hline \multicolumn{5}{|l|}{ Gangguan interaksi sosial } \\
\hline -Tidak ingin tersenyum/tertawa & $94(68.1)$ & $35(25.4)$ & $9(6.5)$ & $0(0)$ \\
\hline -Tidak ingin berbicara & $95(68.8)$ & $33(23.9)$ & $10(7.2)$ & $0(0)$ \\
\hline
\end{tabular}

TP(Tidak Pernah), HTP(Hampir Tidak Pernah), S(Sering), SS(Sangat Sering)

Tabel 2 menunjukkan bahwa sekitar 80 orang anak (58.0\%) sering mengalami gangguan rasa nyeri. Sekitar $44.2 \%$ sering mengalami gangguan fungsional berupa kesulitan minum minuman panas atau dingin. 54.3\% menunjukkan bahwa gangguan fisiologis berupa kesulitan dalam berbicara tidak pernah mengganggu anak beraktifitas. Sekitar $55.1 \%$ masalah karies gigi juga tidak mempengaruhi kehadiran anak di sekolah. Sekitar $42.0 \%$ anak-anak tidak pernah merasa terganggu pada saat tidur. Dan sekitar $64.5 \%$ anak-anak tidak pernah marah serta frustasi dikarenakan masalah kesehatan gigi dan mulut. Sekitar $68.1 \%$ interaksi social anak tidak pernah mengalami gangguan dan selalu tersenyum serta tertawa pada saat mengalami masalah kesehatan gigi dan mulut. Sekitar $68.8 \%$ anak tidak pernah terganggu dengan adanya masalah gigi dan mulut pada saat berkomunikasi.

Tabel 3. Peran orangtua terhadap masalah kesehatan gigi dan mulut anak usia 5-7 tahun

\begin{tabular}{lcccc}
\hline \multirow{2}{*}{ Pernyataan } & \multicolumn{4}{c}{ Pilihan Jawaban } \\
\cline { 2 - 5 } & TP & HTP & S & SS \\
\cline { 2 - 5 } & $\mathbf{n ~ ( \% )}$ & $\mathbf{n ~ ( \% )}$ & $\mathbf{n ~ ( \% )}$ & $\mathbf{n}(\%)$ \\
\hline Kecemasan orangtua & $66(47.8)$ & $39(28.3)$ & $32(23.2)$ & $0(0)$ \\
$\begin{array}{l}\text { Merasa kebingungan } \\
\text { Merasa berasalah }\end{array}$ & $61(44.2)$ & $40(29.0)$ & $34(24.6)$ & $0(0)$ \\
$\begin{array}{l}\text { Meran keluarga } \\
\text { Meninggalkan pekerjaan }\end{array}$ & $89(64.5)$ & $40(29.0)$ & $9(6.5)$ & $0(0)$ \\
Dampakan mepada keuangan & $94(68.1)$ & $29(21.0)$ & $13(9.4)$ & $2(1.4)$ \\
\hline
\end{tabular}

TP(Tidak Pernah), HTP(Hampir Tidak Pernah), S(Sering), SS(Sangat Sering) 
Tabel 3 menunjukkan bahwa sekitar $47.8 \%$ orang tua tidak pernah merasa kebingungan terhadap masalah kesehatan gigi dan mulut anak dan sekitar $44.2 \%$ orang tua tidak pernah merasa bersalah terhadap masalah kesehatan gigi dan mulut anak. Begitu juga dengan masalah pekerjaan orang tua yang ditinggalkan karena masalah kesehatan dan gigi anak. Hal ini menunjukkan sekitar $64.5 \%$ orang tua tidak pernah meninggalkan pekerjaan dikarenakan masalah kesehatan gigi dan mulut anak. Sekitar $68.1 \%$ orang tua mengatakan bahwa masalah kesehatan gigi dan anak tidak pernah berdampak pada keuangan keluarga

Tabel 4. Hasil uji korelasi antara karies gigi dengan kualitas hidup

\begin{tabular}{lccc}
\hline \multirow{2}{*}{ Karies gigi } & \multicolumn{3}{c}{ Kualitas hidup } \\
\cline { 2 - 4 } def & $\mathrm{N}$ & Nilai $r$ & $p$-value \\
decay & & 0.176 & $0.039^{*}$ \\
ekstraksi & \multirow{3}{*}{138} & 0.204 & $0.018^{*}$ \\
filling & & -0.074 & 0.053 \\
\hline
\end{tabular}

Tabel 4 menunjukkan adanya korelasi antara karies gigi dengan kualitas hidup anak usia 5-7 tahun. Hasil pemeriksaan karies gigi diukur menggunakan indeks def untuk gigi sulung dan kualitas hidup diukur menggunakan ECOHIS. Uji statistik dengan menggunakan person correlation diperoleh nilai signifikan untuk karies gigi (def) dengan kualitas hidup adalah 0.039 atau $p<\alpha(p<0.05)$. Namun pada bagian ekstraksi terlihat korelasi negatif, hal ini berarti semakin sedikit ekstraksi diharapkan semakin kecil angka pencabutan pada gigi sulung sehingga memungkinkan kualitas hidup anak lebih baik. Untuk filling terlihat korelasi yang positif, hal ini berarti semakin tinggi angka filling maka diharapkan semakin baik pula kualitas hidupnya. Karies gigi yang telah ditumpat, diharapkan dapat mengembalikan fungsi sehingga tidak mengganggu anak pada proses pengunyahan. Anak usia 5-7 tahun berada dalam periode gigi bercampur. Jumlah gigi sulung pada anak usia 5-7 tahun cenderung dominan. Sedangkan jumlah gigi permanen pada anak usia 5-7 tahun hanya memiliki 6 buah gigi pada rongga mulut. Diantaranya gigi molar 1 rahang atas kanan dan kiri serta molar 1 rahang bawah kanan dan kiri. Gigi insicvus 1 rahang bawah kanan dan kiri.

Sebagian besar karies gigi diderita oleh anak yang berjenis kelamin perempuan dibandingkan anak-anak yang berjenis kelamin laki-laki. Rerata karies gigi sulung 9.05 yang menunjukkan karies gigi yang diderita anak usia 5-7 sebanyak 9 gigi (Tabel 1). Masalah kesehatan gigi dan mulut anak disebabkan oleh banyak faktor diantaranya perilaku anak dan sikap orang tua sebagai pendamping anak dirumah. Adapun faktor yang berasal dari luar rongga mulut yang mempengaruhi terjadinya karies gigi antara lain umur, pola konsumsi makanan, jenis kelamin, ras dan etnis, status sosial ekonomi, tingkat pendidikan dan faktor lingkungan. pengamatan yang dilakukan oleh Milhahn-Turkeheim bahwa karies gigi pada gigi molar pertama lebih tinggi pada wanita dibandingkan dengan pria. ${ }^{33} \mathrm{Hal}$ ini disebabkan karena gigi anak perempuan berada lebih lama di dalam mulut, sehingga lebih lama berhubungan dengan faktor resiko terjadinya karies gigi. ${ }^{14,31}$

Perilaku dan kebiasaan pada anak juga merupakan salah satu faktor penyebab tingginya angka karies gigi. Pola konsumsi kariogenik yang tinggi seperti coklat, roti dan permen merupakan salah satu penyebab terjadinya karies gigi. Sifat makanan kariogenik banyak mengandung karbohidrat dan mudah lengket sehingga dengan mudah bakteri merubah gula menjadi asam. Tidak memperhatikan kebersihan mulut dapat meyebabkan gigi mudah terserang karies pada anak. Anak usia sekolah lebih senang mengkonsumsi makanan kariogenik dibandingkan makanan non kariogenik misalnya buah-buahan. ${ }^{2,3}$ Resiko gigi berlubang pada anak dapat meningkat dengan cepat bila pola makan tidak dikontrol. ${ }^{27}$

Tingginya karies gigi pada anak dapat menyebabkan status kesehatan gigi dan mulut yang jelek. Karies gigi dapat menimbulkan rasa sakit pada gigi, mulut maupun rahang. Invasi bakteri sudah mencapai pulpa gigi dapat menyebabkan rasa sakit yang berdenyut sehingga dapat mempengaruhi aktivitas dan fungsi fisiologis serta psikologis pada anak.11,16,23 Mayoritas rasa sakit yang diakibatkan oleh karies gigi adalah kesulitan makan, menggosok gigi, tidur, bermain dan pergi kesekolah. ${ }^{21}$ Adapun anak usia 3-7 tahun mempunyai 
kemampuan kognitif terbatas untuk menentukan kualitas dan kuantitas rasa nyeri sehingga orang tua juga sulit membedakan dimana letak rasa nyeri yang dikeluhkan oleh anak. ${ }^{23}$ Gangguan fungsional berupa kesulitan makan dan minum (tabel 2) juga berdampak pada proses penyerapan makanan pada tubuh. Hal ini akan mempengaruhi status gizi dan perkembangan yang berakibat pada kualitas hidup anak. ${ }^{6,12}$ Sekitar $17 \%$ ketidakhadiran anak disekolah disebabkan adanya rasa nyeri dan infeksi pada gigi dan mulut. ${ }^{30}$ Karies gigi memiliki dampak pada aktifitas belajar anak, tetapi tidak ada hubungan antara ketidakhadiran maupun gangguan prestasi belajar anak. ${ }^{9}$

Pada penelitian ini sekitar $51.5 \%$ anak mengalami gangguan psikologis berupa kesulitan tidur dan udah marah yang disebabkan adanya karies gigi pada rongga mulutnya Kondisi kesehatan rongga mulut yang jelek juga memungkinkan seseorang merasa terganggu dalam berinteraksi sosial seperti, tersenyum dan tertawa. Anak cenderung lebih banyak menangis dari pada tersenyum ataupun berbicara. ${ }^{12}$

Anak usia 5-7 tahun masih dalam pengawasan orang tua sehingga apapun kondisi yang terjadi pada anak, orang tua sering mengkhawatirkan keadaan anaknya. Rasa bersalah orang tua seperti, kurang tersedianya waktu dalam mendidik atau membesarkan anak, orang tua yang bekerja diluar rumah sehingga perawatan anak dilimpahkan kepada pengasuh atau orang lain. ${ }^{5,7}$ Karies gigi yang tidak diobati juga menyebabkan orang tua merasa bersalah. ${ }^{20}$ Persepsi orang tua juga berhubungan dengan status kesehatan gigi dan mulut anak yang buruk. $^{5}$ Tingkat pendidikan orang tua juga berhubungan dengan pengetahuan orang tua tentang kesehatan gigi dan mulut. ${ }^{1,15,18,28}$

Pekerjaan orang tua dapat mempengaruhi pendapatan keluarga. Orang tua yang memiliki pekerjaan memadai mampu memenuhi kebutuhan sehari-hari dibandingkan orang tua yang tidak memiliki pendapatan. ${ }^{13}$

Faktor lain yang juga mempengaruhi adalah perilaku masyarakat dalam mencari pelayanan kesehatan dan pengobatan sendiri serta jarak dan tempat tinggal dengan pelayanan kesehatan serta biaya yang dibutuhkan untuk pengobatan. ${ }^{3,8}$ Orang tua yang tidak memiliki pekerjaan dapat memiliki efek yang negatif terhadap keluarga maupun sumber pendapatan dibandingkan dengan orang tua yang memiliki pekerjaan dan penghasilan yang memadai. ${ }^{13}$ Dari penghasilan tersebut dapat digunakan sebagai kebutuhan sehari-hari maupun kebutuhan akan kesehatan keluarga. Orang tua yang mengikutsertakan anak dalam program asuransi kesehatan masyarakat lebih memungkinkan mendapat pelayanan kesehatan yang memadai dibandingkan anak yang tidak diikutsertakan dalam program asuransi kesehatan masyarakat. ${ }^{10}$

Asuransi kesehatan memungkinkan orang tua dapat melindungi keluarganya dari gangguan kesehatan baik kesehatan secara umum maupun kesehatan gigi. Orang tua yang mendaftarkan anak-anak mereka dalam program asuransi kesehatan masyarakat lebih memungkinkan mendapat pelayanan kesehatan yang memadai dibandingkan anak-anak yang tidak mengikuti asuransi kesehatan masyarakat ketika orang tua mereka tidak memiliki pekerjaan lagi. ${ }^{10}$

Karies gigi merupakan penyakit pada rongga mulut yang paling sering dikaitkan dengan dampak buruk pada kualitas hidup anak prasekolah maupun anak sekolah. Gangguan yang sering terjadi adalah timbulnya rasa sakit akibat karies gigi yang tidak dirawat, nafsu makan menurun, kesulitan mengunyah, kesulitan makan beberapa makanan dan minum panas/dingin, penurunan berat badan yang disebabkan asupan makanan yang berkurang, kesulitan tidur, perubahan perilaku serta aktifitas belajar terganggu. Semakin tinggi angka karies gigi seseorang maka akan semakin buruk kualitas hidupnya. ${ }^{24}$

\section{KESIMPULAN}


Karies gigi banyak diderita anak usia 5-7 tahun. Rerata karies yang diderita sekitar 9 gigi peranak. Penelitian dengan menggunakan instrumen ECOHIS menunjukkan terdapat hubungan karies gigi dengan kualitas hidup pada anak sekolah usia 5-7 tahun. Peran orangtua sangat diharapkan untuk mengetahui kondisi kesehatan gigi dan mulut anak. Adanya program asuransi kesehatan sangat membantu biaya pengobatan kesehatan gigi dan mulut anak.

\section{DAFTAR PUSTAKA}

Abanto J, Carvalho TS, Mendes FM, Wanderley MT, Bonecker M, Raggio DP: Impact of oral diseases and disorders on oral health-related quality of life of preschool children. Community Dent Oral Epidemiol 2011, 39:105-114.

Adimayanti, E, Haryani, S, Rosidi A, 2013. Hubungan Antara Konsumsi Makanan Kariogenik Dengan Kejadian Karies Gigi Pada Anak SDN 1 Gogodalem, Kec. Bringin, Kab. Semarang. e-Jurnal UNIMUS. Vol.2, No.1.

Adhyka, N., Keloko, A.B., Lubis, N.L., 2013. Gambaran Perilaku Mahasiswa Serumpun Fakultas Kesehatan Universitas Sumatera Utara Terhadap Proses Pencarian Pengobatan Di Kota Medan Tahun. E-journal.com.

Arisman., 2007. Gizi Dalam Daur Kehidupan, Jakarta, EGC.

Arora A, Bedros D, Bhole S, Do LG, Scott J, Blinkhorn A, Schwarz E: Child and family health nurses' experiences of oral health of preschool children: a qualitative approach. $J$ Public Health Dent 2012, 72:149-155.

Baginska, J., 2013. Evaluation of the Status of Primary Dentition in 6-7-Year-Old Children from Bialystok District Using the Mean dmf and the Index of Clinical Consequences of Untreated Caries (pufa). Dent. Med. Probl. 2013, 50, 2, 160-166

Carvalho AC, Paiva SM, Viegas CM, Scarpelli AC, Ferreira FM, Pordeus IA: Impact of Malocclusion on Oral Health-Related Quality of Life among Brazilian Preschool Children: a Population-Based Study. Braz Dent J 2013, 24:655-661.

Embong, M.F., 2010. Gambaran Tingkat Pengetahuan, Sikap, dan Tindakan Pencarian Pelayanan Kesehatan/Pengobatan (Health Seeking Behavior) pada Masyarakat Kelurahan Padang Bulan, Kecamatan Medan Baru. Fakultas Kedokteran USU: Medan.

El-Sayyed, M.H., Khadiga, H.O., Al-Bashir, I. El-Nour., 2015. Prevalence of Dental Caries and its Impact on the Academic Performance of Sudanese Basic School Children, AlSahafa Residental Area (2013-2014). Journal of American Science 2015:11(4).

Fairbrother, G.L., Adam, C. Carle., Amy Cassedy., Paul W. Newacheck., 2010., The Impact of Parental Job Loss on Children's Health Insurance Coverage. J. Health Affairs 29 No.7 (2010) 1343-1349.

Haditono S, Monks F, Knoers A. Psikologi Perkembangan. Yogyakarta. Gadjah Mada University Press. 2006;262-269.

Hartika, DM. 2011. Gambaran Kualita Hidup Anak usia 10-11 Tahun Berdasarkan Status Kesehatan Mulut. Skripsi. Universitas Hasanuddin, FKG. Makassar.

Hong Liu, Zhong Zhao., 2011. Parental job loss and children's health: ten years after the massive layoff of the SOEs' workers in china. China: IZA. 2011: 1-2.

Jenatu, FCP, Wijayanti, CD, Susilo, WH, 2014. Faktor-Faktor Yang Berhubungan dengan timbulnya karies gigi pada siswa-siswi di SD Inpres Tenda-Ruteng Kabupaten Manggarai. Artikel Ilmiah. Program S-1 Keperawatan, STIK SINT Corolus, Jakarta.

Kemthong Mitrakul., Vorawee Laovoravit., Vittawat Vanichanuwat., Attakorn Charatchaiwanna., Attakrit Charatchaiwanna., Weerapol Bunpradit., and Malee Arunakul., 2012. Factor Associated with parent capability on child's oral health care. Southeast Asian Journal Trop Med Public Health; 43(1). 2012: 249-55.

Kidd EAM, Bechal SJ. 2013. Dasar-Dasar Karies Penyakit dan Penanggulangannya. Alih Bahasa. Suwaminata, N dan Yuwono, L. EGC, Jakarta. 
Kemenkes R.I, 2013., Riset Kesehatan Dasar, Badan Penelitian dan Pengembangan, Kementrian Kesehatan Republik Indonesia.

Kramer PF, Ardenghi TM, Ferreira S, Fischer LA, Cardoso L, Feldens CA: Use of dental services by preschool children in Canela, Rio Grande do Sul State, Brazil. Cad Saude Publica 2008, 24:150-156.

Kwan, SYI, Peterson PE, Pine CM, Boruta A. 2005. Health Promoting School: an Opportunity For Oral Health Promotion, Bulletin of WHO.p 677-585.

Lee GHM, McGrath C, Yiu CKY, King NM: A comparison of a generic and oral health-specific measure in assessing the impact of early childhood caries on quality of life. Community Dent Oral Epidemiol 2010, 38:333-339.

Moure-leite, F.R., Ramos-Jorge, J., Ramos-Jorge, M.L., Paiva, S.M., Vale, M.P., Pordeus, I.A., 2011. Impact of Dental Pain on Daily Living of Five-Year-Old Brazilian Preschool Children: Prevalence and Associated Factor. J. Eur Arch. Paediatr Dent. 2011, Dec; 12(6) 293-7.

Notohartojo IT, A. Magdarina D, 2013. Penilaian Indeks DMF-T Anak Usia 12 Tahun Oleh Dokter Gigi dan Bukan Dokter Gigi di Kabupaten Ketapang Propinsi Kalimantan Barat. Media Litbangkes Vol.23 No.1. Maret 2013:41-46

Nelson, 2000. Ilmu Kesehatan Anak Vol. 1 Edisi 15. EGC. Jakarta.

Patabang, E., 2015. Status Karies Gigi dan Kualitas Hidup Lansia di Kabupaten Wajo Tahun 2015. Skripsi. FKG, UNHAS, Makassar.

Peker K, Uysal O, Bermek G, 2011. Cross-cultural adaptation and Preliminary Validation of The Turkish Version of The Early Chiladhood Oral Health Impact Scale Among 5-6 Year-Old Children. Health and Quality of life Outcomes. 9:118.

Pratiwi, R dan Mutmainah R, 2013. Gambaran Keparahan Karies Pada Anak Usia 6,9 dan 12 Tahun di Kabupaten Pinrang, Sulawesi Selatan Menggunkan Indeks PUFA/pufa. Dentofasial. Vo.12 No. 2

Sariningsih, E, 2013. Merawat Gigi Anak Sejak Usia Dini. PT. Elex Media Komputindo. Jakarta.

Scarpelli, AN, Oliveira, BH, Tesch, FC, Leao, AT, Pordeus, IA, Paiva, SM, 2011. Psychometric properties of the Brazilian version of the Early Childhood Oral Health Impact Scale (BECOHIS). BMC Oral Health. Vol.11:9.

Seiham A, 2005. Oral Health, General Health and Quality of Life, Bulletin of the World Health Organization.

Stephani, L.J., William, F.Vann Jr., Jonathan B. Kotch., Bahuna, T. Pahel., Jessica Y. Lee., 2011. Impact of Poor Oral Health on Children's School Attendance and Performance. Am.J. Public Health, 2011. October 101(10):1900-1906.

Suwelo I. 1992. Karies Gigi Pada Anak dengan Berbagai Faktor Etiologi, EGC, Jakarta, 1992.

Sriyono N, 2009. Pengantar IImu Kedokteran Gigi Pencegahan, Medika, Fakultas UGM, Yogyakarta.

Tarigan, R, 2014. Karies Gigi. Edisi 2. EGC. Jakarta.

Wala HC, Wicaksono DA, Tambunan E, 2014. Gambaran Status Karies Gigi Anak Usia 11 12 Tahun Pada Keluarga Pemegang JAMKESMAS di Kelurahan Tumantang I Kec. Tomohon Selatan. Jurnal e-GiGi Vol 2, No. 1 